\title{
Sanksi Kasepekang Dalam Hukum Adat Bali
}

\author{
I Ketut Sukadana, Diah Gayatri Sudibya dan Ni Made Sukaryati Karma \\ Fakultas Hukum Universitas Warmadewa, Denpasar, Bali-Indonesia \\ sukadana.fhunwar@gmail.com
}

Published: 30/01/2021

\begin{abstract}
How To Cite:
Sukadana, I. K., Sudibya, D. G., \& Karma, N. M. S. (2021). Sanksi Kasepekang Dalam Hukum Adat Bali. KERTHA WICAKSANA: Sarana Komunikasi Dosen dan Mahasiswa. 15(1). Pp 72-79. https:// doi.org/10.22225/kw.15.1.2819.72-79
\end{abstract}

\begin{abstract}
Abstrak
Desa adat di Bali sebagaimana kini diatur melalui Peraturan Daerah Provinsi Bali Nomor 4 Tahun 2019, memiliki sistem pemerintahan yang sama. Kegiatan yang dilakukan dalam desa adat meliputi bidang adat dan keagamaan, dimana suatu desa adat di Bali memiliki aturan adat tersendiri yang dituangkan dalam awig-awig desa. Pemerintahan desa adat bersifat otonom, dalam arti setiap desa adat mempunyai aturan tesendiri yang hanya berlaku bagi warga desa/ banjar yang bersangkutan. Secara umum aturan-aturan yang tertuang dalam awig-awig sama sekali tidak boleh bertentangan dengan peraturan yang berlaku baik di tingkat nasional maupun daerah. Tetapi dalam kenyataannya masih ditemukan awig-awig dibeberapa desa adat yang memuat sanksi yang tidak cocok lagi dengan perkembangan jaman, seperti misalnya masih menerapkan sanksi adat kasepekang yaitu pengucilan dari pergaulan hidup bersama. Pengucilan warga masyarakat ini tidak tanggung-tanggung, bahkan ada yang sampai menutup akses ke luar dari tanah pekarangan rumahnya. Permasalahan yang dikaji dalam penelitian ini: (1) pengaturan sanksi dalam hukum adat Bali, dan (2) Faktor yang menjadi alasan diterapkannya sanksi adat kasepekang. Tipe penelitian ini adalah empiris dengan teknik pengumpulan data menggunakan wawancara terhadap informan. Berdasarkan hasil penelitian dapat disampaikan bahwa pengaturan sanksi adat tercantum dalam awig-awig setiap desa adat yaitu indik pamidanda (perihal sanksi); Adapun yang menjadi alasan masih diterapkannya sanksi kasepekang dalam kehidupan masyarakat adalah karena yang bersangkutan bersikap keterlaluan dan sulit dibina, disamping jenis sanksi ini tercantum dalam awig-awig sehingga prajuru adat (pemimpin adat) masih mempunyai landasan hukum untuk menerapkannya.
\end{abstract}

Kata Kunci: Hukum Adat Bali; Pelanggaran Awig-Awig; Sanksi Adat; Pengucilan

\begin{abstract}
Traditional villages in Bali as now regulated through the Bali Provincial Regulation Number 4 of 2019, have the same government system. Activities carried out in traditional villages cover the custom and religious fields, where a traditional village in Bali has its own customary rules which are outlined in the village awig-awig. Customary village government is autonomous, meaning that each customary village has its own rules which only apply to the residents of the village / banjar concerned. In general, the rules contained in awig-awig must not at all conflict with the prevailing regulations at the national or regional levels. But in reality there are still awig-awig in some traditional villages that contain sanctions that are no longer suitable to the times, such as still applying the Kasepekang customary sanction, namely exclusion from the association of living together. The exclusion of members of the community is not half-hearted, and some have even closed off access to the outside of their home yard. The problems examined in this study: (1) the regulation of sanctions in Balinese customary law, and (2) the factors that become the reasons for the implementation of the kasepekang customary sanctions. This type of research is empirical with data collection techniques using interviews with informants. Based on the research results, it can be said that the customary sanctions arrangements are listed in the awig-awig of each customary village, namely indik pamidanda (regarding sanctions); As for the reason that the kasepekang sanction is still being applied in people's lives is because the person concerned is outrageous and difficult to foster, besides this type of sanction is stated in awig-awig so that the prajuru adat (traditional leader) still has a legal basis to apply it.
\end{abstract}

Keywords: Balinese Customary Law; Violation Of Awig-Awig; Customary Sanctions; Exclusion 


\section{PENDAHULUAN}

Desa adat memiliki sistem pemerintahan yang hampir sama diseluruh Bali, yaitu terdiri dari Bendesa Adat atau Kelian Adat sebagai kepala desa adat, Petajuh Bendesa sebagai wakilnya, penyarikan sebagai sekretaris, patengen sebagai bendahara, Sinoman atau Kasinoman sebagai juru arah (Sirtha, 2008). Anggota desa adat dinamakan sebagai krama adat atau sering disebut krama desa. Namun a da juga di beberapa tempat, krama tersebut digolongkan lagi menurut status pribadi dan perkawinannya. Prajuru desa adat merupakan perangkat desa adat yang berfungsi untuk senantiasa menjaga kesuciaan dan keselarasan serta keserasian kehidupan dalam desa adat dengan menjaga ketertiban, keamanan dalam arti yang dinamis bersama-sama segenap anggota masyarakat adatnya, guna mewujudkan kesejahteraan dan kebahagiaan lahir dan batin.

Prajuru desa adat dalam melaksanakan tugasnya, berpegang kepada aturan-aturan yang ditentukan dalam awig-awig yang di dalamnya memiliki satua-satuan kahyangan tiga. Secara garis besar awig-awig mengatur hubungan anggota masyarakat adat dalam keyakinannya terhadap Tuhan Yang Maha Esa / Sanghyang Widhi Wasa, hubungan antar sesama anggota masyarakat adat dan hubungan anggota masyarakat dengan wilayah dan lingkungannya (Windia, 2014).

Kegiatan yang dilakukan dalam desa adat meliputi bidang adat dan keagamaan, dimana suatu desa adat di Bali memiliki aturan adat tersendiri yang dituangkan dalam awig-awig desa. Dari segi pemerintahan adat, masingmasing desa adat bersifat otonom, dalam arti setiap desa adat mempunyai aturan tesendiri yang hanya berlaku bagi warga desa/ banjar yang bersangkutan. Sifat otonom desa adat di atas meliputi pengaturan warga melalui pembuatan awig-awig ataupun pararem. Isi awig-awig pada suatu desa adat tertentu masih dijumpai ada yang tidak sesuai dengan perkembangan jaman, utamanya dalam perihal sanksi terlebih lagi dalam implementasinya. Suatu hal yang menonjol dalam hal penerapan sanksi kasepekang yang tidak sesuai dengan nilai-nilai Pancasila dan atau Hak Asasi Manusia (HAM).

Pada penelitian sebelumnya, (Wibawa \& Wiradnyana, 2017) menemukan bahwa sanksi kasepekang dinilai melanggar HAM karena sanksi kasepekang terhadap seseorang, itu berarti orang yang bersangkutan tidak diajak bertegur sapa atau berkomunikasi padahal dalam rumusan HAM terkait dengan hak atas kebebasan informasi menyebutkan setiap orang berhak untuk berkomunikasi dan memperoleh informasi untuk mengembangkan pribadi dan lingkungan sosialnya. Berdasarkan hal tersebut maka permasalahan yang dibahas dalam artikel ini adalah Bagaimana pengaturan sanksi dalam Hukum Adat Bali dan Mengapa sanksi adat kasepekang masih diterapkan pada masyarakat?.

\section{HASIL DAN PEMBAHASAN}

\section{Pengakuan Terhadap Hukum Adat}

Hukum adat adalah sistem hukum yang dikenal dalam lingkungan kehidupan sosial di Indonesia dan juga beberapa negara di Asia. Hukum adat tersebut bersumber dari peraturan hukum tidak tertulis yang tumbuh dan berkembang serta dipertahankan berdasarkan kesadaran hukum masyarakatnya.

Berbagai aturan hukum tidak tertulis terbentuk dari berbagai kebiasaan-kebiasaan dalam pergaulan hidup masyarakat, selanjutnya dipandang sebagai adat dan pada akhirnya dipakai sebagai kaidah bersanksi. Masyarakat bersangkutan sebagai pengguna tetap memberikan penghormatan sehingga terus dipertahankan karena dirasakan memberikan manfaat yaitu kedamaian dalam pergaulan.

Hukum adat dapat eksis di lingkungan masyarakat oleh karena mengandung nilai-nilai yang sejalan dengan jiwa masyarakat bersangkutan. Berkaitan dengan hukum adat ini terdapat unsur yang menguatkan hukum adat itu yaitu sanksi hukum adat itu sendiri. Adat merupakan suatu peraturan, kebiasaan-kebiasaan, yang tumbuh dan terbentuk dari suatu masyarakat atau daerah yang dianggap memiliki nilai yang dijunjung masyarakatnya. Adat telah melembaga dalam kehidupan masyarakat yang berupa tradisi atau kebiasaan mampu mengendalikan perilaku warga masyarakatnya.

Hukum Adat adalah Hukum Non Statuir yang berarti Hukum Adat pada umumnya memang belum/ tidak tertulis. Oleh karena itu dilihat dari mata seorang ahli hukum memperdalam pengetahuan hukum adatnya dengan pikiran juga dengan perasaan pula. Jika dibuka dan dikaji lebih lanjut maka akan ditemukan peraturanperaturan dalam hukum adat yang mempunyai sanksi dimana ada kaidah yang tidak boleh dilanggar dan apabila dilanggar maka akan 
dapat dituntut dan kemudian dihukum. Definisi dari hukum adat sendiri adalah suatu hukum yang hidup karena dia menjelmakan perasaan hukum yang nyata dari rakyat sesuai dengan fitrahnya sendiri, hukum adat terus menerus dalam keadaan tumbuh dan berkembang seperti hidup itu sendiri.

Apabila ditelusuri banyak para ahli hukum yang meberikan definisi mengenai hukum adat diantaranya Prof. Soepomo, merumuskan hukum adat adalah synomim dari hukum yang tidak tertulis di dalam peraturan legislative (statuary law), hukum yang hidup sebagai konvensi di badan-badan hukum Negara (Parlemen, Dewan Propinsi dan sebagainya), hukum yang hidup sebagai peraturan kebiasaan yang dipertahankan di dalam pergaulan hidup, baik di kota maupun di desa-desa. Soekanto juga merumuskan hukum adat sebagai komplek adat adat inilah yang kebanyakan tidak dikitabkan, tidak dikodifikasikan dan bersifat paksaan mempunyai sanksi (dari itu hukum), jadi mempunyai akibat hukum, komplek ini disebut Hukum Adat. Suroyo Wignjodipuro mengemukakan pendapat adat adalah suatu kompleks norma-norma yang bersumber apada perasaan keadilan rakyat yang selalu berkembang serta meliputi peraturan tingkat laku manusia dalam kehidupan sehari-hari dalam masyarakat, sebagian besar tidak tertulis, karena mempunyai akibat hukum (sanksi). Dan tokoh yang terkenakl seperti Van Vallenhoven yang pertama kali menyebut hukum adat memberikan definisi hukum adat sebagai himpunan peraturan tentang perilaku yang berlaku bagi orang pribumi dan timur asing pada satu pihak yang mempunyai sanksi (karena bersifat hukum) dan pada pihak lain berada dalam keadaan tidak dikodifikasikan (karena adat). Abdulrahman selanjutnya menegaskan rumusan Van Vallenhoven dimaksud memang cocok untuk mendeskripsikan apa yang dinamakan Adat Recht pada jaman tersebut bukan untuk Hukum Adat pada masa kini.

Ada empat fungsi yang berkaitan dengan hakhak tradisional dalam persekutuan masyarakat pedesaan berkenan dengan menjaga tata harmoni antara masyarakat dengan tata semesta meliputi : fungsi pemerintahan, fungsi pemeliharaan roh, fungsi pemeliharaan agama, fungsi pembinaan hukum adat (Koesnoe, 1979). Hukum adat yang dikenal sebagai hukum tidak tertulis jika ditelusuri dalam sejarahnya sudah diakui keberadaannya sudah sejak jaman penjajahan Belanda, misalnya adanya hukum yang berlaku sesuai dengan penggolongan penduduk berdasarkan ketentuan Pasal 131 Indische Staatregeling (IS). Demikian pula setelah kemerdekaan, hukum adat telah mendapat pengakuan sesuai tercantum dalam Aturan Peralihan Pasal II Undang-Undang Dasar 1945.

Apabila dihubungkan dengan peraturan perundang-undangan (hukum positif) dalam system hukum Indonesia, sistem hukum nasional akan mendahulukan hukum tertulis dari hukum tidak hukum tidak tertulis jika terjadi benturan. Jika hukum tertulis tidak mengatur maka hukum tidak tertulis otomatis diberlakukan. Jadi peran hukum adat sebagai hukum tidak tertulis bersifat anvullend (mengisi) terhadap hukum tertulis. Sistem hukum tertulis dan hukum tidak tertulis keduanya saling melengkapi satu sama lain, sekalipun hukum tertulis mendapat prioritas. Walaupun hukum adat berbeda dengan undangundang, hukum adat tetap mempunyai kekuatan yang legal karena masyarakat tetap menaatinya. Baik hukum tertulis maupun hukum tidak tertulis masing-masing mempunyai kebaikan dan kelemahan (Ranggawidjaja, 1998).

Berbicara mengenai hukum adat maka tidak bisa terlepas dari masyarakat hukum adat. Apabila dilihat dari segi terminologis maka dapat dijabarkan bahwa Masyarakat adalah suatu sistem dari kebiasaan, tata cara, dari wewenang dan kerja sama antara berbagai kelompok, penggolongan, dan pengawasan tingkah laku serta kebiasaankebiasaan manusia. Masyarakat merupakan suatu bentuk kehidupan bersama untuk jangka waktu yang cukup lama sehingga menghasilkan suatu adat istiadat, masyarakat merupakan setiap kelompok manusia yang telah hidup dan bekerja bersama cukup lama, sehingga mereka dapat mengatur diri mereka dan menganggap diri mereka sebagai suatu kesatuan sosial dengan batas-batas yang dirumuskan dengan jelas sedangkan masyarakat adalah orang-orang yang hidup bersama yang menghasilkan kebudayaan dan mereka mempunyai kesamaan wilayah, identitas, mempunyai kebiasaan, tradisi, sikap, dan perasaan persatuan yang diikat oleh kesamaan.

Hukum adat memandang masyarakat sebagai suatu jenis hidup bersama dimana manusia memandang sesamanya manusia sebagai tujuan bersama. Sistem kehidupan bersama menimbulkan kebudayaan karena setiap anggota kelompok merasa dirinya terikat satu dengan yang lainnya. Beberapa pendapat para ahli di atas dapat disimpulkan masyarakat memiliki arti ikut 
serta atau berpartisipasi, sedangkan dalam bahasa Inggris disebut society. Bisa dikatakan bahwa masyarakat adalah sekumpulan manusia yang berinteraksi dalam suatu hubungan sosial. Mereka mempunyai kesamaan budaya, wilayah, dan identitas, mempunyai kebiasaan, tradisi, sikap, dan perasaan persatuan yang diikat oleh kesamaan.

Istilah masyarakat hukum adat sering juga disebut dengan persekutuan hukum adat yang pada hakekatnya merupakan terjemahan dari adatrechtsgmeenschap. Masyarakat Indonesia yang terdiri dari berbagai corak dan struktur kemasyarakatannya beraneka ragam dan sebagian terbesar penduduknya bermukim di pedesaan. Beberapa ahli membedakan istilah masyarakat hukum adat dengan masyarakat adat. Masyarakat hokum adat merupakan terjemahan dari adatrechtsgmeenschap dan masyarakat hokum merupakan terjemahan indigenous people (Samosir, 2013).

Hukum Adat Bali adalah komplek normanorma, baik dalam wujud tertulis maupun tidak tertulis, berisi perintah, kebolehan dan larangan, yang mengatur kehidupan masyarakat Bali yang menyangkut hubungan antara manusia, hubungan manusia dengan alam, dan manusia dengan Tuhannya. Apabila keharmonisan hubungan ini terganggu maka haruslah ada upaya-upaya atau tindakan-tindakan hukum yang mengembalikan keseimbangan tersebut, berupa reaksi adat atau sanksi adat (Sudantra \& Parwata, 2006).

\section{Sanksi Adat dan Penerapannya}

Sanksi adat merupakan salah satu reaksi adat terhadap tidak dilaksanakannya peraturanperaturan adat sanksi ini dimaksudkan untuk mengembalikan keseimbangan yang terganggu akibat adanya pelanggaran adat. Sanksi adat ini selalu disertai dengan suatu kejadian atau perbuatan yang harus dipertanggungjawabkan oleh si pelaku maupun keluarganya. Biasanya, perbuatan atau kejadian dalam melakukannya sanksi adat itu selalu disertai dengan upacara yang di Bali dikenal dengan istilah pemarisuddhan yaitu upacara pembersihan desa (adat) dari perasaan kotor alam gaib (Suartha, 2015).

Desa Adat sebagai kesatuan masyarakat hukum adat yang ada di Provinsi Bali mempunyai suatu kesatuan tradisi dan tata krama pergaulan hidup masyarakat umat Hindu secara turun temurun berada dalam ikatan Kahyangan Tiga
(Kahyangan Desa) yang mempunyai wilayah dan harta kekayaan sendiri serta berhak mengurus rumah tangganya sendiri. Hukum adat yang ada di Bali selama ini hanya berdasarkan kata sepakat yang tertuang dalam awig-awig dan pararem, yakni sanksi berupa teguran serta peringatan bagi yang melakukan kesalahan atau kejahatan. Dapat diartikan ini sebatas tindakan adat atas pelanggaran warganya sesuai aturan yang disepakati.

Awig-awig desa Adat ini berisi aturan yang bersifat mengatur dan memaksa masyarakat untuk tercipta keserasian dan keselaran setiap hubungan hukum dalam masyarakat. Awig-awig tersebut dibuat dan ditetapkan oleh krama desa berdasarkan kesepakatan bersama dan ditaati oleh krama desa itu sendiri dan yang terpenting adalah awig-awig itu merupakan pengikat persatuan dan kesatuan krama desa guna menjamin adanya kekompakan dan keutuhan dalam menyatukan tujuan bersama, mewujudkan kehidupan yang aman, tentram, tertib dan sejahtera demi kedamaian desa. secara garis besar awig-awig merupakan kontrol sosial yang berfungsi mempertahankan kaidah-kaidah/nilainilai yang ada. bertujuan untuk mengembalikan keseimbangan yang terganggu dengan menjatuhkan sanksi negatif terhadap warga yang melanggar atau menyimpang dari nilai-nilai atau kaidah-kaidah yang berlaku.

Terhadap suatu peraturan masyarakat wajib untuk mematuhinya, termasuk juga di desa adat yang mempunyai peraturan atau awig-awig, apabila dilanggar akan dikenakan sanksi adat. Ada salah satu sanksi yang sangat ditakuti oleh masyarakat di desa adat yaitu sanksi kasepekang. Dikarenakan hak dan kewajiban mereka dibatasi dan berlaku juga bagi keturunannya, misalnya dilarang ikut serta dalam ayah-ayahan (gotongroyong), persembahyangan di pura, penggunaan balai banjar, tidak mendapatkan pemangku (pendeta) saat melakukan upacara, tidak diajak berbicara, dikucilkan, dan tidak mendapatkan tempat pemakaman di desa. Warga yang sudah terkena sanksi kasepekang bermaksud ingin kembali menjadi warga setempat kemungkinan bisa dikembalikan lagi setelah memenuhi syarat dan kewajibannya untuk membayar semacam penanjung batu (ganti kerugian) atau upacara guru piduka (memohon pengampunan).

Dilihat dari soal tata masyarakat di Bali, maka tidak akan berlebihan jika awig-awig itulah yang menonjol paling ke depan dimasyarakat adat. 
Awig-awig yang lekat dengan soal-soal "terdalam disegi lahir dan batin masyarakat adat, dan ini bukan hal yang ajaib sebab awig-awig itu mengatur secara horizontal hubungan masyarakat, juga mengatur hubungan vertikal masyarakat secara individu atau kelompok kepada Sang Hyang Widhi Wasa (Tuhan Yang Maha Esa). Sanksi adat selalu tumbuh sejalan dengan perjalanan penghormatan tata dan kemanfaatan tata untuk masyarakat. Kaidah-kaidah hukum adat yang tidak sesuai lagi dengan jiwa dan rasa kepatuhan masyarakat, otomatis akan ditinggalkan. Sedang yang masih selaras akan selalu terbawa oleh perkembangan dan kaidahkaidah yang dianggap patut serta perlu untuk memelihara perjalanan kehidupan masyarakat akan tumbuh lagi melingkari masyarakat lain (Artadi, 2003).

Membahas awig-awig Berbicara soal tata yang satu ini di Bali, tidak lepas dari berbagai macam bentuk lain yang pada kenyataannya sering dikaburkan pengertiannya. Menurut pengamatan pada berbagai desa di Bali terlihat adanya tata dalam nama lain yang disebut sebagai sima, peswara/titiswara. Kedua hal tersebut dasarnya juga menunjuk kepada soal kaidah yang mengatur segi-segi kehidupan masyarakat adat. Namun kemudian untuk memperjelas dimana letak awig-awig itu diantara macam bentuk tata tadi, maka dapat ditegaskan bahwa yang dimaksud dengan sima adalah suatu tata masyarakat adat yang umumnya tidak tertulis namun ditaati turun temurun. Sedangkan paswara adalah suatu tata lain yang penjelmaannya dari kehendak penguasa zaman dulu (raja-raja) yang pada hakikatnya juga untuk mengatur kehidupan masyarakat adat.

Awig-awig pada dasarnya itu tumbuh dari bawah yaitu dari ketulusan masyarakat adat untuk kepentingan ketentraman dan keharmonisan masyarakat adat itu sendiri. Sedangkan di jaman kini segala peraturan yang ditimpakan kepada masyarakat untuk mengatur kehidupan dalam rangka bernegara. Dengan demikian dapat ditegaskan bahwa awig-awig yang tumbuh dan mengikuti perkembangan masyarakat mampunyai kekuatan berlaku karena ia lekat dan diperlukan karena dirasa mutlak untuk tentram.

Awig-awig di Bali sekiranya perlu dicarikan jalan penyegarannya dimasa yang akan datang dalam arti bahwa awig-awig itu tidak hanya untuk diakui saja tetapi diperhatikan keadaannya yang bisa saja bergesekan dengan hukum tertulis lainnya. Kepastian hukum yang dikejar oleh hukum positif itu berbenturan dengan kabutuhan keseimbangan dan harmonisasi kelompok masyarakat adat yang diatur oleh awig-awig masyarakat adat di Bali.

Disetiap desa adat mempunyai awig-awig, dan warga desa adat sangat menghargai pararem dan awig-awig dan bahkan ada kecenderungan bahwa mereka lebih takut sanksi adat dibanding terhadap sanksi hukum Negara. Karena begitu patuhnya adat mereka, maka ada kecenderungan bahwa keluarga besar mengikat warga Bali dimanapun ia berada. Awig-awig di desa adat yang satu bisa berbeda dengan awig-awig di desa lain, dikarenakan atas kesepakatan warga maka awig-awig dapat diubah, walaupun untuk perubahan bukan suatu hal yang mudah, oleh karena mesti mengikuti ketentuan sebagaimana diatur dalam pawos nguwah-nguwuhin awig-awig (pasal khusus yang mengatur perihal ketentuan mengubah awig-awig).

Jelaslah bahwa eksistensi sanksi adat di Bali sangat kuat, dan menyeluruh untuk aturan hukum di masyarakat utamanya di kawasan desa adat. Hal ini disebabkan semuanya telah mengacu pada landasan filosofis masyarakat adat Bali yakni tri kaya parisuda dan tri hita karana. Pemberlakuan awig-awig yang ada di Desa Adat, sanksi adat (danda / pamidanda) masih eksis dan berlaku di lingkungan masyarakat adat. Apabila ada masyarakat yang melakukan pelanggaran peraturan maka yang bersangkutan akan dikenakan sanksi adat.

Sanksi adat merupakan suatu reaksi adat terhadap pelanggaran aturan-aturan adat usahausaha yang dilakukan untuk mengembalikan ketidakseimbangan pula termasuk pula ketidakseimbangan yang bersifat magis akibat adanya gangguan yang merupakan pelanggaran adat. Di dalam awig-awig reaksi adat atau sanksi adat dikenal dengan istilah pamidanda.

Sebagai kesatuan masyarakat hukum adat, Desa Adat diikat oleh aturan adat atau hukum adat yang tumbuh dan berkembangan dalam lingkungan masyarakat setempat, yang lebih dikenal adalah dalam bentuk awig-awig yang merupakan pedoman dasar dari desa adat dalam pemerintahannya. Apabila ada krama desa adat yang melanggar aturan desa akan dikenakan sanksi adat.

Desa Adat di Bali sebagai kesatuan masyarakat adat memilik berbagai jenis sanksi 
adat, seperti dapat klasifikasikan menjadi tiga, yang dikenal dengan tri danda (tiga sanksi) yang terdiri dari : Arta Danda, Jiwa Danda dan Sangaskara Danda (Windia \& Sudantra, 2006).

Arta Danda yaitu sanksi berupa harta benda atau benda-benda materiil, Contohnya

- Danda artha, seperti : dosa, danda saha panikel-nikelnya miwah panikel urunan. (denda berupa uang beserta denda-denda yang lainnya).

- Kataban. (diambil dan dimiliki).

- Kedaut karang ayahan desanya. (diambil-alih tempat kediamannya yang berupa karang ayahan desa).

- Kerampag (harta miliknya diambil paksa atau dirampas).

- Ganti rugi berupa benda-benda materiil.

- Ngingu banjar/desa (menjamu seluruh anggota banjar/desa).

Jiwa Danda (sanksi berupa penderitaan jasmani dan rohani/jiwa). Contoh :

- Kapademang (dibunuh).

- Katugel limane (dipotong tangannya).

- Sangaskara, pemarisuda, prayascita, (upacara pembersihan).

- Mengaksama, mapilaku, lumaku, mengolasolas, nyuaka. (minta maaf).

- Matirta gemana atau matirta yatra (melakukan perjalanan suci, untuk golongan pendeta).

- Kaselong (dibuang ke luar kerajaan bahkan adakalanya ke luar Bali).

- Mapulang ke pasih. (ditenggelamkan ke laut).

- Kablagbag (dipasung).

- Katundung, kairid. (diusir).

- Kasepekang, kanoroyang (tidak diajak ngomong/dikucilkan).

- Ayahan panukun kasisipan (wajib kerja pengganti kesalahan).

- Kawusang mabanjar/madesa adat (diberhentikan sebagai warga desa/banjar).

- Tan polih suaran kulkul matehin pikenoh kapuikin. (untuk sementara dianggap bukan warga, yang ditandai dengan tidak mendapatkan pemberitahuan sesuatu atau sama dengan dikucilkan).

- Kalatengan. (disiksa menggunakan daun lateng).

- Kaople (diarak keliling desa).

- Kapelungguh, kapesajen, karepotang (diberi peringatan lisan).

- Ganti rugi immateriil (mengawini gadis).

- Kagingsiran (ditempatkan sementara dekat kuburan atau di luar tegak desa).

Sangaskara Danda (sanksi berupa pelaksanaan upacara tertentu, sesuai dengan ajaran agama Hindu). Contohnya: pelaksanaan upacara pemarisuda, prayascita, dan lain-lain upacara pembersihan yang dimaksudkan untuk mengembalikan keseimbangan magis.

Khusus untuk jenis sanksi kasepekang, desa adat di Bali banyak mencantumkan dalam awigawig, terutama awig-awig yang sudah lama disuratkan. kasepekang berasal dari kata sepi ikang yang mempunyai arti 'tidak diajak bicara' atau 'dikucilkan'. dan pendapat lainnya kasepekang berasal dari kata sepek yang mengandung arti 'mempermasalahkan dihadapan orang'. Kamus Bali-Indonesia yang dikeluarkan Dinas Pendidikan Dasar Provinsi Bali, kata sepek diartikan sebagai 'kucilkan', sedangkan kasepekang sama dengan 'dikucilkan'. Dengan demikian kasepekang artinya tidak diajak ngomong, kasepekang banjar artinya tidak diajak ngomong oleh seluruh anggota banjar dan atau warga adat setempat.

Perihal jenis-jenis sanksi adat dalam hukum adat Bali dapat ditemukan pengaturannya dalam satu sarggah (bab) tersendiri yang berjudul "wicara lan pamidanda" dalam setiap awig-awig, sedangkan besaran sanksinya biasanya diatur dalam pararem masing-masing desa adat. Sarggah ini dibagi dalam dua palet (bagian) yaitu indik wicara (perihal pelanggaran/sengketa/peristiwa hukum) dan indik pamidanda (perihal sanksi) selanjutnya tertuang dalam beberapa pawos (pasal).

Untuk prosedur penanganan wicara, dalam awig-awig sudah ditetapkan dengan pola penyelesaian oleh prajuru desa, berdasarkan bukti dan saksi serta bila perlu mohon pertimbangan pemerintah atau pihak berwenang. Apabila pihak pelanggar tetap tidak mengikuti maka yang 
bersangkutan tidak diperkenankan menggunanakan fasilitas mili desa adat.

Sanksi adat di Bali sangat kuat, dan menyeluruh untuk aturan hukum di masyarakat, semuanya mengacu pada landasan filosofis hukum adat yakni tri kaya parisuda dan tri hita karana. Dalam awig-awig yang ada di Desa Adat, sanksi adat (danda / pamidanda) masih eksis dan berlaku di lingkungan masyarakat adat. Apabila ada masyarakat yang melakukan pelanggaran peraturan maka yang bersangkutan akan dikenakan sanksi adat.

Berdasarkan hasil penelitian yang telah dilakukan pada beberapa awig-awig menunjukkan bahwa telah terjadi perubahan berbagai jenis sanksi. Banyak sanksi yang tidak sesuai lagi dengan perkembangan jaman, tidak termuat lagi dalam awig-awig. Untuk artha danda, sanksi kataban (diambil dan dimiliki), kerampag (harta miliknya diambil paksa atau dirampas) sudah tidak nampak lagi. Sedangkan untuk klasifikasi sanksi jiwa danda, beberapa jenis sanksi yang sudah tidak diberlakuan: kapademang (dibunuh), katugel limane (dipotong tangannya), kaselong (dibuang ke luar kerajaan), mapulang ke pasih. (ditenggelamkan ke laut), kablagbag (dipasung), kalatengan (disiksa menggunakan daun yang menyebabkan gatal luar biasa), dan kaople (diarak keliling desa).

Khusus untuk jenis sanksi kasepekang, desa adat di Bali masih banyak mencantumkan dalam awig-awig, terutama awig-awig yang sudah lama disuratkan. Kasepekang merupakan sanksi adat yang ditakuti dikalangan masyarakat, dikarenakan orang yang terkena sanksi ini tidak boleh mengikuti ayah-ayahan desa, tidak mendapatkan layanan banjar, tidak boleh menggunakan fasilitas milik desa adat termasuk setra (kuburan) dan tidak diajak berkomunikasi di masyarakat. Pelaksanaan sanksi adat kasepekang, di dalammya mengandung unsur pengucilan atau diskriminatif. Sanksi adat kasepekang ini apabila dihubungkan dengan ketentuan hukum positif yang berlaku secara nasional khususnya UndangUndang Nomor 39 Tahun 1999 Tentang Hak Asasi Manusia (HAM) tampaknya terjadi hal yang bertentangan.

Sekalipun dapat diklasifikasikan bertentangan dengan Hak Asasi Manusia (HAM), pelaksanaan sanksi adat kasepekang masih saja terjadi. Berdasarkan hasil wawancara dengan I Made Wijaya, SE (Bendesa Desa Adat Tanjung Benoa, Kuta Selatan, Badung), adapun yang menjadi alasan masih diterapkannya sanksi kasepekang dalam kehidupan masyarakat adalah karena yang bersangkutan bersikap keterlaluan dan sulit dibina, sehingga dianggap melawan desa adat. Pendapat lainnya disampaikan oleh I Gusti Ngurah Bagus Putra, SH, (Bendesa Desa Adat Sulang, Kecamatan Dawan, Klungkung) bahwa jenis sanksi ini masih tercantum dalam awig-awig sehingga prajuru adat (pemimpin adat) mempunyai landasan hukum untuk menerapkan terhadap masyarakat yang melakukan pelanggaran adat. Hanya saja prajuru adat tidak gegabah menerapkan begitu saja sanksi dalam awig-awig, warga akan diberikan kesempatan untuk memperbaiki diri, tetapi justru si pelanggar yang pergi meninggalkan desa dan bukan karena diusir.

\section{SIMPULAN}

Dari uraian diatas maka penulis memberikan kesimpulan bahwa apabila kita menghubungkan dengan dengan peraturan perundang-undangan (hukum positif) dalam system hukum Indonesia, sistem hukum nasional akan mendahulukan hukum tertulis dari hukum tidak hukum tidak tertulis jika terjadi benturan. Jika hukum tertulis tidak mengatur maka hukum tidak tertulis otomatis diberlakukan. Jadi peran hukum adat sebagai hukum tidak tertulis bersifat anvullend (mengisi) terhadap hukum tertulis. Sistem hukum tertulis dan hukum tidak tertulis keduanya saling melengkapi satu sama lain, sekalipun hukum tertulis mendapat prioritas. Walaupun hukum adat berbeda dengan undang-undang, hukum adat tetap mempunyai kekuatan yang legal karena masyarakat tetap menaatinya. Baik hukum tertulis maupun hukum tidak tertulis masing-masing mempunyai kebaikan dan kelemahan. Tetapi apabila kita melihat di Bali yang sangat kental adat istiadatnya terlihat bahwa disetiap desa adat mempunyai awig-awig, dan warga desa adat sangat menghargai pararem dan awig-awig dan bahkan ada kecenderungan bahwa mereka lebih takut sanksi adat dibanding terhadap sanksi hukum Negara. Karena begitu patuhnya adat mereka, maka ada kecenderungan bahwa keluarga besar mengikat warga Bali dimanapun ia berada. Awig-awig di desa adat yang satu bisa berbeda dengan awig-awig di desa lain, dikarenakan atas kesepakatan warga maka awig-awig dapat diubah, walaupun untuk perubahan bukan suatu hal yang mudah, oleh karena mesti mengikuti ketentuan sebagaimana diatur dalam pawos nguwah-nguwuhin awig-awig (pasal khusus yang mengatur perihal ketentuan mengubah awig- 
awig).

Dari hal tersebut sudah dapat kita lihat bahwa jelaslah eksistensi sanksi adat di Bali sangat kuat , dan menyeluruh untuk aturan hukum di masyarakat utamanya di kawasan desa adat. Hal ini disebabkan semuanya telah mengacu pada landasan filosofis masyarakat adat Bali yakni tri kaya parisuda dan tri hita karana. Pemberlakuan awig-awig yang ada di Desa Adat, sanksi adat (danda / pamidanda) masih eksis dan berlaku di lingkungan masyarakat adat. Apabila ada masyarakat yang melakukan pelanggaran peraturan maka yang bersangkutan akan dikenakan sanksi adat. Sanksi adat merupakan suatu reaksi adat terhadap pelanggaran aturanaturan adat usaha-usaha yang dilakukan untuk mengembalikan ketidakseimbangan pula termasuk pula ketidakseimbangan yang bersifat magis akibat adanya gangguan yang merupakan pelanggaran adat. Di dalam awig-awig reaksi adat atau sanksi adat dikenal dengan istilah pamidanda.

Khusus untuk jenis sanksi kasepekang, desa adat di Bali masih banyak mencantumkan dalam awig-awig, terutama awig-awig yang sudah lama disuratkan. Kasepekang merupakan sanksi adat yang ditakuti dikalangan masyarakat, dikarenakan orang yang terkena sanksi ini tidak boleh mengikuti ayah-ayahan desa, tidak mendapatkan layanan banjar, tidak boleh menggunakan fasilitas milik desa adat termasuk setra (kuburan) dan tidak diajak berkomunikasi di masyarakat. Pelaksanaan sanksi adat kasepekang, di dalammya mengandung unsur pengucilan atau diskriminatif. Sanksi adat kasepekang ini apabila dihubungkan dengan ketentuan hukum positif yang berlaku secara nasional khususnya UndangUndang Nomor 39 Tahun 1999 Tentang Hak Asasi Manusia (HAM) tampaknya terjadi hal yang bertentangan.

Sekalipun dapat diklasifikasikan bertentangan dengan Hak Asasi Manusia (HAM), pelaksanaan sanksi adat kasepekang masih saja terjadi. Berdasarkan hasil wawancara dengan I Made Wijaya, SE (Bendesa Desa Adat Tanjung Benoa, Kuta Selatan, Badung), adapun yang menjadi alasan masih diterapkannya sanksi kasepekang dalam kehidupan masyarakat adalah karena yang bersangkutan bersikap keterlaluan dan sulit dibina, sehingga dianggap melawan desa adat. Pendapat lainnya disampaikan oleh I Gusti Ngurah Bagus Putra, SH, (Bendesa Desa Adat Sulang, Kecamatan Dawan, Klungkung) bahwa jenis sanksi ini masih tercantum dalam awig-awig sehingga prajuru adat (pemimpin adat) mempunyai landasan hukum untuk menerapkan terhadap masyarakat yang melakukan pelanggaran adat. Hanya saja prajuru adat tidak gegabah menerapkan begitu saja sanksi dalam awig-awig, warga akan diberikan kesempatan untuk memperbaiki diri, tetapi justru si pelanggar yang pergi meninggalkan desa dan bukan karena diusir.

\section{DAFTAR PUSTAKA}

Artadi, I. K. (2003). Hukum Adat Bali Dengan Aneka Masalahnya. Denpasar: Pustaka Bali Post.

Koesnoe, M. (1979). Catatan-catatan Terhadap Hukum Adat Dewasa Ini. Surabaya: Airlangga. University Press.

Ranggawidjaja, R. (1998). Pengantar Ilmu PerundangUndangan Indonesia. Bandung: Mandar Maju.

Samosir, D. (2013). Hukum Adat Indonesia, Eksistensi dalam Dinamika Perkembangan Hukum di Indonesia. Bandung: CV. Nuansa Auli.

Sirtha, I. N. (2008). Aspek Hukum Dalam Konflik Adat di Bali. Denpasar: Universitas Udayana.

Suartha, I. D. M. (2015). Hukum dan Sanksi Adat, Perspektif Pembaharuan Hukum Pidana. Malang: Setara Press.

Sudantra, I. K., \& Parwata, A. A. (2006). Memahami Awig-awig Desa Pakaraman, Pamidanda, Pemberdayaan Desa Pakraman Dalam Penyelesaian Perkara di Luar Pengadilan. Denpasar: Udayana University Press.

Wibawa, G. Y. S., \& Wiradnyana, I. G. A. (2017). Implementasi Hukum Adat Dengan Sanksi Kasepekang Ditinjau Dari Perspektif Hak Asasi Manusia. Pariksa, 1(1). Retrieved from https:// jurnal.stahnmpukuturan.ac.id/index.php/ pariksa/article/view/648

Windia, W. P. (2014). Hukum Adat Bali Aneka Kasus Dan Penyelesaiannya. Denpasar: Udayana University Press.

Windia, W. P., \& Sudantra, I. K. (2006). Pengantar Hukum Adat Bali. Denpasar: Udayana University Press. 